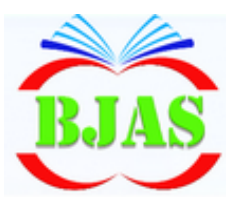

Available online at: http//bjas.bajas.edu.iq

College of Agriculture, University of Basrah

DOi:10.21276/basjas

ISSN $1814-5868$

Basrah J. Agric. Sci., 32(Spec Issue): 59-69, 2019

\section{Basrah \\ Journal of \\ Agricultural \\ Sciences}

E-ISSN: 2520-0860

\title{
Effect of The Date and Concentrations of The IBA on Rooting and Growth of Semi-Hard Wood Cuttings of Two Olive (Olea europaea L.) Varieties
}

\author{
Nabil M. Ameen Al-Imam ${ }^{1 *}$ \& Qais Qassim Hamid ${ }^{2}$ \\ ${ }^{1}$ Department of Horticulture and Landscape Design, College of Agriculture and Forestry, \\ University of Mosul, Iraq \\ ${ }^{2}$ Director General of the municipalities of Karamian, Ministry of municipalities and \\ Tourism, Iraq. \\ *Corresponding author e-mail: nabil_alimam2000@yahoo.com
}

Received 6 April 2019; Accepted 1 June 2019; Available online 1 September 2019

\begin{abstract}
This study was conducted in the plastic house at the Department of Horticulture and Landscape Design - College of Agriculture and Forestry - University of Mosul, Iraq. For the period from 1/2/2013 until 1/8/2013. To study the effect of three dates of cutting collection from $1^{\text {st }}$ February to $1^{\text {st }}$ April monthly intervals, and soaking the cuttings in four concentrations of IBA solution $0,2000,3000,4000 \mathrm{mg} . \mathrm{l}^{-1}$ seconds on the rooting ability and subsequent growth of semi-hard wood cuttings of two olive varieties Gordal Sevillano and Tanche. The results were showed the cuttings were collected on the $1^{\text {st }}$ of March resulted into the highest of rooted cutting, survival $\%$, carbohydrate content, carbohydrate to nitrogen $(\mathrm{C} / \mathrm{N}$ ratio) in the basal cuttings. Rooting increased proportionately with increasing of IBA concentrations principally the cuttings were soaked in $4000 \mathrm{mg} \cdot \mathrm{l}^{-1}$. Gordal Sevillano cuttings gave a significantly increase of rooting and the basal cuttings gave a significantly increased of carbohydrates content than Tanche variety. The best rooting percentage were get from interaction between Gordal Sevillano which collected on the $1^{\text {st }}$ of March treated with $4000 \mathrm{mg} . \mathrm{l}^{-1}$ were gave $66.67 \%$. Highest rate of survival $(80.0 \%)$ of control treatment of Tanche olive variety were taken on $1^{\text {st }}$ of February. The highest content of carbohydrate (18.10) were obtained in Gordal Sevillano basal cuttings were taken on $1^{\text {st }}$ of March. Higher percentage of Nitrogen (1.58\%) were obtained from interaction between basal cutting of Gordal Sevillano variety. were taken on $1^{\text {st }}$ of March. The highest percentage of $\mathrm{C} / \mathrm{N}$ ration were got by interaction of Gordal Sevillano which collected on $1^{\text {st }}$ of March.
\end{abstract}

Keywords: Date, IBA, Rooting, Semi-Hard Wood, Cuttings, Olive, Olea europaea.

\section{Introduction}

Olive (Olea europaea L.) is an evergreen fruit trees that belong to the Oleaceae family. The vegetative method of olive propagation is the economic method used in the production of seedlings and uses different types of cuttings. The method of soft wood stems is the most common one in the multiplication of various olive varieties on the commercial scale for the 


\section{Al-Imam \& Hamid / Basrah J. Agric. Sci., 32 (Special Issue): 59-69, 2019}

possibility of processing them in large numbers and their economical production. The success of rooting the olive cuttings varies according to the varieties used for propagation. There are easy, medium and difficult varieties of rooting (Ruiz \& Loreto, 1998). In their study, Ullah et al. (2012) investigated the possibility of rooting five varieties of olives (Azerbaijan, Uslu and Improved Nabali, Manzallino and Leccio) and found that the best rooting of cuttings is that of Azerbaijan compared to other varieties.

Hechmi et al., (2013) noted in their study of the propagation of the olive cuttings of the varieties of Picual, Koroueiki, Arbeguina, that the highest percentage of rooting and the percentage of survival of cuttings is that of Koroueiki, and Arbeguina compared to Picual. Jindia (2003), explained that the date of collection the cuttings and the nutritional status of the mother trees play a role in the success of the rooting of cuttings. Ling \& Zhong (2012), in their study of olive cuttings propagation, reported that the high concentration of carbohydrates in the growth season coincided with a high percentage of rooting. Al-Imam (2011), observed in their study of the propagation of the olive cuttings of the variety of Manzanillo that the highest percentage of rooting of cuttings is $87.30 \%$ when taken the cuttings on the first of May and treated with $3000 \mathrm{mg}$ IBA. $\mathrm{l}^{-1}$.

Al-Dolaemi (2012) noted in her study to propagate the olive cuttings of the varieties of Ashrassi and Shamlali that the highest percentage of rooting is $93.33 \%$ of the cuttings taken in mid-October. The use of Auxin has a significant role in improving the rates of rooting of the cuttings, especially the (IBA) (Indole-3 butyric acid) as many studies have pointed to the importance of the use of Auxin in the propagation of the stem cuttings of olives. The use of Auxins (especially Indole-3 butyric acid IBA) have a significant role in improving the rates of nodal cutting rooting, where many studies pointed out the importance of Auxins in the propagation of olive by stem cuttings. Maghsudlu et al. (2013) in their study of propagation of the cuttings of two olive varieties Mission and Koroneiki, treated with five concentrations of the IBA $(0,2500,3000,3500$ and $4000 \mathrm{mg}$ IBA. ${ }^{-1}$ ) showed that the highest percentage is $(74.58 \%)$ at the treatment of cuttings at a concentration of $3500 \mathrm{mg}$ IBA. $\mathrm{l}^{-1}$. Hechmi et al. (2013) in their study of the propagation of the olive cuttings of Picual, Koroueiki, Arbeguina varieties and IBA treated with a concentration of 0 and $4000 \mathrm{mg}$ IBA. $\mathrm{l}^{-1}$, noted that they obtained the highest percentage of rooting and the percentage of survival $85.1 \%$ and $98 \%$ ) respectively of treatment of the cuttings at a concentration of (4000 mg IBA. $\mathrm{l}^{-}$ $\left.{ }^{1}\right)$.

The aim of this search were to study of the timing of the taking of the cuttings and treatment with the various concentrations of IBA (Indole-3 butyric acid) of two varieties of olives planted in Nineveh Horticulture Station, Mosul, to obtaining the highest percentage of rooting of Tanche and Gordal Sevillano varieties with semi-hard-wood cuttings.

\section{Materials \& Methods}

This study was carried out in the plastic house of the Department of Horticulture and Landscape Design, College of Agriculture and Forestry, University of Mosul from the period $1 / 2 / 2013$ to $1 / 8 / 2013$, polyethylene cover has been lifted and the green network (Saran) was put from the beginning of May to avoid high temperature.

Cuttings of two varieties of olive Tanche and Gordal Sevillano. $15 \mathrm{~cm}$ long with two 


\section{Al-Imam \& Hamid / Basrah J. Agric. Sci., 32 (Special Issue): 59-69, 2019}

leaves each and 4-6 $\mathrm{mm}$ diameter were taken from eight years old trees, growing at the Horticulture Research Station of Nineveh, Mosul, Iraq. The basal of the cuttings was immersed in Indole butyric acid (IBA) at 0, 2000, 3000 and 4000 mg. $\mathrm{l}^{-1}$ for 5 minutes. After treatment the cuttings were planted in the soil medium sand and bits $(1: 1)$ ratio in wooden propagation boxes. 10 cuttings were planting $(5 \mathrm{~cm})$ between the cuttings and $10 \mathrm{~cm}$ between one line and another. After planting the experimental area was irrigated. The factorial experiment was laid out in Complete Randomized Design (CRD) with three replications. There were 10 cuttings per treatment. Duncan's Multiple Range Test was used to compare the averages of treatments at a probability level (5\%). Roger \& Hasted, 2003). After four months of planting each time. The data regarding percentage of rooting $(\%)$, survival $\%$, total carbohydrates $\%$. The amount of carbohydrates was calculated in the bases of the cuttings before it was planting and according to Dubois et al. (1956). The readings were taken using the APEL PD-303 spectrophotometer. The ratio of nitrogen in the bases of the cuts was calculated using the Micro-Kjeldahl and according to the method given by Alsahaf (1989). Then calculating the ratio of carbohydrates to nitrogen $(\mathrm{C} / \mathrm{N}$ ratio). The mean of the parameters were separated according to Duncan's Multiple Range Test was used to compare the averages of treatments at a probability level 5\% (Roger \& Hasted, 2003).

\section{Results \& Discussion}

\section{The percentage of cuttings rooting :}

Table (1) exhibited that the dates of taking the cuttings have a clear effect on the increase in the percentage of the olive cuttings. The date of taking the cuttings on 1 March and the first of April was significantly better than the percentage of rooting the olive cuttings taken on $1^{\text {st }}$ February. This may be due to an increase in the percentage of carbohydrates in the cuttings taken at that date (Table 3 ) than on other dates and this stock is used in the process of rooting.

The process of photosynthesis in the cuttings is low because of the small number of leaves in it so it has a little impact in the content of carbohydrates and the adoption of the cuttings at the beginning of rooting on stored carbohydrates, or because the cuttings contain IAA-like materials as they change in different seasons. which has a positive effect in increasing the percentage of rooting (Wiesman \& Lavee, 1995; Souidan et al., 1995; Al-Dolaemi, 2012)

Table (1) indicated that the treatment of the olive cuttings with all the concentrations of IBA (4000, 3000 and 2000) mg. $\mathrm{l}^{-1}$ showed a significant increase in the rooting ratio compared to the control treatment $\left(0 \mathrm{mg} . \mathrm{l}^{-1}\right)$. It was also found that treatment of the cuttings at a concentration of (3000 mg. $\left.\mathrm{l}^{-1}\right)$ gave the highest rooting rate of the cuts $(44.444 \%)$ and significantly differed $(21.389 \%)$, while this difference was not significant compared with the two treatments of the cuttings 2000 and 4000 mg IBA. $\mathrm{l}^{-1}$.

Values with similar characters for each factor or their interactions individually do not significantly differ under the Duncan Multiplicity test below the $5 \%$ probability level.

This is attributed to the effective role and IBA's ability to stimulate the formation of roots in the cuttings and may be due to its effect on the cell meristems, elongation and increment of cell divisions, and the formation of lateral root principles. 
Al-Imam \& Hamid / Basrah J. Agric. Sci., 32 (Special Issue): 59-69, 2019

Table (1): Effect of the time of cuttings collection and the IBA concentrations in the percentage of the cuttings rooting of Tanche and Gordal Sevillano olive varieties.

\begin{tabular}{|c|c|c|c|c|c|c|}
\hline \multirow{2}{*}{$\begin{array}{c}\text { Cuttings } \\
\text { collection dates }\end{array}$} & \multirow{2}{*}{ Variety } & \multicolumn{4}{|c|}{ IBA concentrations $\mathrm{mg} / \mathrm{l}^{-1}$} & \multirow{2}{*}{$\begin{array}{c}\text { Interaction } \\
\text { dates } \times \text { variety }\end{array}$} \\
\hline & & 0 & 2000 & 3000 & 4000 & \\
\hline \multirow{4}{*}{1 February } & \multirow{2}{*}{ Tanche } & 33.33 & 46.76 & 50 & 36.76 & 41.667 \\
\hline & & $b-g$ & $a-d$ & $a-d$ & $b-f$ & $\mathrm{a}$ \\
\hline & \multirow{2}{*}{$\begin{array}{c}\text { Gordal } \\
\text { Sevillano }\end{array}$} & 3.33 & 10 & 23.33 & 13.33 & 12.500 \\
\hline & & $\mathrm{h}$ & fgh & $d-h$ & fgh & $\mathrm{c}$ \\
\hline \multirow{4}{*}{$1 \mathrm{March}$} & \multirow{2}{*}{ Tanche } & 13.33 & 33.33 & 43.33 & 18.33 & 27.083 \\
\hline & & fgh & $b-g$ & $a-e$ & $e-h$ & $\mathrm{~b}$ \\
\hline & \multirow{2}{*}{$\begin{array}{c}\text { Gordal } \\
\text { Sevillano }\end{array}$} & 43.33 & 46.67 & 56.67 & 66.67 & 53.333 \\
\hline & & $\mathrm{a}-\mathrm{e}$ & $\mathrm{abc}$ & $\mathrm{ab}$ & $\mathrm{a}$ & a \\
\hline \multirow{4}{*}{1 April } & \multirow{2}{*}{ Tanche } & 8.33 & 33.33 & 36.67 & 36.67 & 28.750 \\
\hline & & gh & $b-g$ & $b-f$ & $b-f$ & $\mathrm{~b}$ \\
\hline & \multirow{2}{*}{$\begin{array}{l}\text { Gordal } \\
\text { Sevillano }\end{array}$} & 26.67 & 60 & 56.67 & 53.33 & 41.167 \\
\hline & & $\mathrm{d}-\mathrm{h}$ & $\mathrm{ab}$ & $\mathrm{ab}$ & $\mathrm{abc}$ & $\mathrm{a}$ \\
\hline \multicolumn{6}{|c|}{ Interaction Dates $\times$ IBA } & Dates effect \\
\hline \multirow{2}{*}{\multicolumn{2}{|c|}{1 February }} & 18.333 & 28.333 & 36.667 & 25 & 27.083 \\
\hline & & $\mathrm{d}$ & bcd & $\mathrm{abc}$ & $\mathrm{cd}$ & $\mathrm{b}$ \\
\hline \multirow{2}{*}{\multicolumn{2}{|c|}{1 March }} & 28.333 & 40 & 50 & 42.500 & 40.208 \\
\hline & & bcd & $a b c$ & $\mathrm{a}$ & $a b c$ & $\mathrm{a}$ \\
\hline \multirow{2}{*}{\multicolumn{2}{|c|}{1 April }} & 17.500 & 46.667 & 46.667 & 45 & 38.958 \\
\hline & & $\mathrm{d}$ & $a b$ & $\mathrm{ab}$ & $a b$ & $\mathrm{a}$ \\
\hline \multicolumn{6}{|c|}{ Interaction IBA $\times$ Variety } & Variety effect \\
\hline \multirow{2}{*}{\multicolumn{2}{|c|}{ Tanche }} & 18.333 & 37.778 & 43.333 & 30.556 & 32.500 \\
\hline & & $\mathrm{d}$ & $\mathrm{abc}$ & $\mathrm{ab}$ & bcd & $\mathrm{b}$ \\
\hline \multirow{2}{*}{\multicolumn{2}{|c|}{ Gordal Sevillano }} & 24.444 & 38.889 & 45.556 & 44.444 & 38.333 \\
\hline & & $\mathrm{cd}$ & $\mathrm{ab}$ & $\mathrm{a}$ & $a b$ & $\mathrm{a}$ \\
\hline \multirow{2}{*}{\multicolumn{2}{|c|}{ IBA effect }} & 21.389 & 38.333 & 44.444 & 37.500 & \\
\hline & & $\mathrm{b}$ & $\mathrm{a}$ & $\mathrm{a}$ & $\mathrm{a}$ & \\
\hline
\end{tabular}

Means within columns with the same letter are not significantly different at $P=0.05$. 


\section{Al-Imam \& Hamid / Basrah J. Agric. Sci., 32 (Special Issue): 59-69, 2019}

The cortical and pulp cells of the auxin-treated cuttings become non-specialized and regenerate which leads to formation of Callus cells and root primordial (Barcelo et al., 1999; Wynne \& Mcdonald, 2002; Hopkins \& Hüner, 2004; Al-Dolaemi, 2012) and that the IBA not only increases the natural IAA but increases IAAsp which promotes the formation of lateral roots and its growth (Garcia et al., 1994). It increases the speed of gathering and attracting nutrients and some factors that encourage the growth of the leaves and the apical growing and when making the cuttings, which stimulates rooting. It is clear from the same table data that the variety has a significant effect on the increase in the percentage of rooting. Goral Sevillano significantly increased the percentage of rooting on the Tanche variety. The reason for the superiority of the variety type is that it is due to genetic factors related to the variety of biomaterials. The Gordal Sevillano was higher in carbohydrate content than in Tanche (Table 3)

Carbohydrates are a major source of energy needed by plants in their various vital activities, including the process of formation, growth and development of roots (Hartmann et al., 2014) which positively reflected the increase in rooting percentage. Table (1) data explained that the interaction between the dates of taking the cuttings with the concentrations of the IBA and the varieties had a significant effect on the increase in the percentage of the olive cuttings.

Olive cuttings of Gordal Sevillano taken on the $1^{\text {st }}$ of March treated with the concentration of (4000 mg IBA. $\left.\mathrm{l}^{-1}\right)$. recorded the highest increase of rooting (66.67\%) compared with most of the treatments. Whereas cuts of Tanche species taken on 1 February and treated with $3000 \mathrm{mg}$ IBA. $\mathrm{l}^{-1}$ concentration achieved the highest increase in the percentage of the rooting of the cuttings $(50,000 \%)$, while the lowest values of the rooting (3.33\%) was for Gordal Sevillano taken in Feb $1^{\text {st }}$. This may be due to the combined effect of the three factors under study and the reasons cited for interpreting each factor separately.

\section{Survival percentage of cuttings:}

It is clear from the data in table (2) that the dates of taking the cuttings have a clear effect on increasing the survival rate of the living olive cuttings which has formed green growths and has not yet developed roots. The date of taking the cuttings on $1^{\text {st }}$ February is significantly higher than the other two dates of March and the first of April. The high survival rate of the cuttings taken during the first date of February, may explain that the rate of rooting on this date was low.

The decrease in temperature and relative humidity at this date led to the survival of the cuttings for a long time without drying and not rooting. The low rate of survival to the cuttings in the first dates of March and the first of April may be due to the large proportion of the cuts that have been rooted. This led to small number of cuttings remaining at these two dates. Table (3) also showed that the concentrations of (IBA) did not significantly increase the survival rate of the cuttings. The cuttings of control were significantly superior to that treated with the (IBA) concentration in the survival rate of the cuttings. The lowest values in the survival ratio of cuttings treated with $\left(3000\right.$ mgIBA. $\mathrm{l}^{-1}$ concentration. The result of this finding was attributed to the fact that all IBA concentrations resulted in a significant increase in the percentage of rooting compared with the treatment of the control sample, which led to a higher survival rate of the control cuttings, which differed significantly with the cuttings treated with all IBA 


\section{Al-Imam \& Hamid / Basrah J. Agric. Sci., 32 (Special Issue): 59-69, 2019}

concentrations. The same table revealed that the variety did not have a significant effect on increasing the survival rate of the olive cuttings. It is clear from the data in table (2) that the timing of the taking of the cuttings with the concentrations of (IBA) has a clear and significant effect on increasing the survival rate of the cuttings. Tanche Control cuttings taken on $1^{\text {st }}$ of Feb. were significantly superior in survival percentage of $(80 \%)$.

The cuttings of Gordal Sevillano had the highest rate of survival (50\%)in the treatment of the control and the date taken on the first of February. While the cuttings of Gordal Sevillano taken on the first day of February and treated with concentration $\left(3000 \mathrm{mg} \mathrm{IBA.1}^{-}\right.$ $\left.{ }^{1}\right)$ recorded the lowest survival rate of $33.3 \%$. This may be due to the combined effect of the three factors under study and the reasons mentioned to explain each factor separately.

\section{Carbohydrate percentage in the bases of the cuttings:}

It is clear from table (3) that the timing of taking the cuttings has a clear effect in increasing the percentage of carbohydrates in the bases of the cuttings of the olive, as the date of taking the cuttings on the first of March significantly exceeded the cuttings taken in the other dates. Results may be interpreted on the basis that taking the cuttings on the first date of the plants were in the growth stage, which helped to manufacture carbohydrates and proteins and then the formation of enzymes that are responsible for most of the biological construction processes and then lead to the building of internal hormones that are promoters of growth.

The low carbohydrates ratio on the first day of February may be due to the fact that the trees from which the cuttings are taken at this time were in a dormant phase, meaning that they contain a high percentage of inhibitors such as the Abscisic acid (ABA), which in turn inhibits the formation of the alpha-amylase enzyme. This may be due to the fact that the high concentration of carbohydrates in the growth season coincides with the high percentage of rooting (Ling \& Zhong, 2012). Table (3) also presented that the variety has a significant effect on the increase in the proportion of carbohydrates in the bases of the cuttings, where olive cuttings of the Gordal Sevillano variety were significantly exceeded the cuttings of the Tanche in the proportion of carbohydrates, the explanation of this result may be attributed to the genetic differences between the two varieties. The same table indicated that the interaction of the dates of taking the cuttings with the variety has a clear effect on the increase in the percentage of carbohydrates in the bases of the cuttings, as the olive cuttings of the type Gordal Sevillano which was obtained on the first of March $(1,722 \%)$ significantly exceeded the rest of the cuttings of other olive in the rate of carbohydrate.

\section{Nitrogen percentage $(\%)$ in the bases of the cuttings:}

Table (4) exhibited that the dates of collection of the cuttings have not increase the nitrogen percentage of the bases of olive cuttings.

\section{Ratio of carbohydrates to nitrogen (C / N ratio):}

It is clear from the data in table (5) that the timing of taking the cuttings has a clear effect on the increase in the ratio of carbohydrates to nitrogen ( $\mathrm{C} / \mathrm{N}$ ratio). The cuttings obtained on March 1 in the ratio of carbohydrate to nitrogen $(\mathrm{C} / \mathrm{N}$ ratio) reached $(0.782 \%)$ significantly $\mathrm{On}$ the other two dates. 
Al-Imam \& Hamid / Basrah J. Agric. Sci., 32 (Special Issue): 59-69, 2019

Table (2): Effect of the time of cuttings collection and the IBA concentrations in the survival percentage of Tanche and Gordal Sevillano olive varieties.

\begin{tabular}{|c|c|c|c|c|c|c|}
\hline \multirow{2}{*}{$\begin{array}{c}\text { Cuttings collection } \\
\text { dates }\end{array}$} & \multirow{2}{*}{ Variety } & \multicolumn{4}{|c|}{ IBA concentrations mg. $\mathrm{l}^{-1}$} & \multirow{2}{*}{$\begin{array}{c}\text { Interaction dates } \\
\times \text { variety }\end{array}$} \\
\hline & & 0 & 2000 & 3000 & 4000 & \\
\hline \multirow{4}{*}{1 February } & \multirow{2}{*}{ Tanche } & 80 & 30 & 20 & 30 & 33.33 \\
\hline & & $\mathrm{a}$ & $\mathrm{cg}$ & d-g & $c-g$ & $\mathrm{~b}$ \\
\hline & \multirow{2}{*}{$\begin{array}{c}\text { Gordal } \\
\text { Sevillano }\end{array}$} & 50 & 40 & 3.33 & 36.67 & 32.500 \\
\hline & & $\mathrm{bc}$ & $\mathrm{bc}$ & $\mathrm{g}$ & bf & $\mathrm{b}$ \\
\hline \multirow{4}{*}{$1 \mathrm{March}$} & \multirow{2}{*}{ Tanche } & 53.33 & 63.33 & 30 & 36.67 & 52.500 \\
\hline & & $\mathrm{bc}$ & $\mathrm{ab}$ & $\mathrm{c}-\mathrm{g}$ & $b-f$ & $\mathrm{a}$ \\
\hline & \multirow{2}{*}{$\begin{array}{l}\text { Gordal } \\
\text { Sevillano }\end{array}$} & 43.33 & 36.67 & 40 & 40 & 40 \\
\hline & & bcd & $b-f$ & b-e & b-e & $\mathrm{b}$ \\
\hline \multirow{4}{*}{1 April } & \multirow{2}{*}{ Tanche } & 13.33 & 16.67 & 6.67 & 13.333 & 12.500 \\
\hline & & efg & d-g & g & efg & $\mathrm{c}$ \\
\hline & \multirow{2}{*}{$\begin{array}{c}\text { Gordal } \\
\text { Sevillano }\end{array}$} & 20 & 10 & 16.67 & 16.67 & 15.833 \\
\hline & & $d-g$ & $\mathrm{fg}$ & $\mathrm{dg}$ & $d-g$ & $\mathrm{c}$ \\
\hline \multicolumn{6}{|c|}{ Interaction Dates $\times$ IBA } & Dates effect \\
\hline \multirow{2}{*}{\multicolumn{2}{|c|}{1 February }} & 51.667 & 35 & 11.665 & 33.333 & 46.250 \\
\hline & & $\mathrm{ab}$ & $\mathrm{b}$ & $\mathrm{c}$ & $\mathrm{b}$ & $\mathrm{a}$ \\
\hline \multirow{2}{*}{\multicolumn{2}{|c|}{1 March }} & 61.667 & 50 & 35 & 38.333 & 32.917 \\
\hline & & a & $\mathrm{ab}$ & $\mathrm{b}$ & $\mathrm{b}$ & $b$ \\
\hline \multirow{2}{*}{\multicolumn{2}{|c|}{1 April }} & 16.667 & 13.333 & 11.667 & 15 & 14.167 \\
\hline & & $\mathrm{c}$ & $\mathrm{c}$ & $\mathrm{c}$ & $\mathrm{c}$ & $\mathrm{c}$ \\
\hline \multicolumn{6}{|c|}{ Interaction $\mathrm{IBA} \times$ Variety } & Variety effect \\
\hline \multirow{2}{*}{\multicolumn{2}{|c|}{ Tanche }} & 48.889 & 36.667 & 18.889 & 26.667 & 32.778 \\
\hline & & $\mathrm{a}$ & $\mathrm{ab}$ & $\mathrm{c}$ & $\mathrm{c}$ & $\mathrm{a}$ \\
\hline \multirow{2}{*}{\multicolumn{2}{|c|}{ Gordal Sevillano }} & 37.778 & 28.889 & 20 & 31.111 & 29.444 \\
\hline & & $\mathrm{ab}$ & $\mathrm{bc}$ & $\mathrm{c}$ & $\mathrm{c}$ & $\mathrm{a}$ \\
\hline \multirow{2}{*}{\multicolumn{2}{|c|}{ IBA effect }} & 43.333 & 32.778 & 19.444 & 28.889 & \\
\hline & & $\mathrm{a}$ & $\mathrm{b}$ & $\mathrm{c}$ & $\mathrm{c}$ & \\
\hline
\end{tabular}

Means within columns with the same letter are not significantly different at $P=0.05$. 
Al-Imam \& Hamid / Basrah J. Agric. Sci., 32 (Special Issue): 59-69, 2019

Table (3): Effect of the time of cuttings collection in the carbohydrate percentage (\%) in the bases of the cuttings of Tanche and Gordal Sevillano olive varieties.

\begin{tabular}{|c|c|c|c|}
\hline \multirow{2}{*}{ Cuttings collection dates } & \multicolumn{2}{|c|}{ Variety } & \multirow{2}{*}{ Dates effect } \\
\hline & Tanche & Gordal Sevillano & \\
\hline \multirow{2}{*}{1 February } & 0.840 & 0.154 & 0.497 \\
\hline & $\mathrm{b}$ & $\mathrm{d}$ & $\mathrm{b}$ \\
\hline \multirow{2}{*}{$1 \mathrm{March}$} & 0.693 & 1.722 & 1.207 \\
\hline & $\mathrm{c}$ & $\mathrm{a}$ & a \\
\hline \multirow{2}{*}{1 April } & 0.163 & 0.767 & 0.465 \\
\hline & $\mathrm{d}$ & $\mathrm{cd}$ & $\mathrm{b}$ \\
\hline \multirow{2}{*}{ Variety effect } & 0.565 & 0.881 & \\
\hline & $\mathrm{b}$ & $\mathrm{a}$ & \\
\hline
\end{tabular}

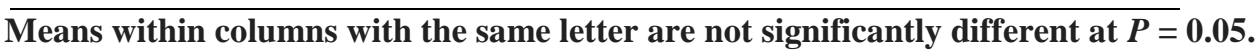

Table (4): Effect of the time of collection of the cuttings in the Nitrogen percentage $(\%)$ in the bases of the cuttings of Tanche and Gordal Sevillano olive varieties.

\begin{tabular}{cccc}
\hline \multirow{2}{*}{$\begin{array}{c}\text { Cuttings collection } \\
\text { dates }\end{array}$} & \multicolumn{2}{c}{ Variety } & Dates effect \\
\cline { 2 - 3 } Tanche & Gordal Sevillano & \\
\hline \multirow{2}{*}{1 February } & 1.47 & 1.38 & 1.42 \\
& $\mathrm{ab}$ & $\mathrm{b}$ & $\mathrm{a}$ \\
\hline 1 March & 1.45 & 1.58 & 1.51 \\
& $\mathrm{ab}$ & $\mathrm{a}$ & $\mathrm{a}$ \\
\hline \multirow{2}{*}{1 April } & 1.50 & 1.47 & 1.48 \\
& $\mathrm{ab}$ & $\mathrm{ab}$ & $\mathrm{a}$ \\
\hline Variety effect & 1.47 & 1.48 & \\
\hline
\end{tabular}

Means within columns with the same letter are not significantly different at $P=0.05$.

Ratio of carbohydrates to nitrogen (C / N ratio):

It is clear from the data in table (5) that the timing of taking the cuttings has a clear effect on the increase in the ratio of carbohydrates to nitrogen $(\mathrm{C} / \mathrm{N}$ ratio). The cuttings obtained on
March 1 in the ratio of carbohydrate to nitrogen $(\mathrm{C} / \mathrm{N}$ ratio) reached $(0.782 \%)$ significantly $\mathrm{On}$ the other two dates. The explanation for this result was the increase in carbohydrate content at this time and no difference in the ratio of nitrogen during the time of taking the reason, which led to an 
Al-Imam \& Hamid / Basrah J. Agric. Sci., 32 (Special Issue): 59-69, 2019

Table (5): Effect of the time of cuttings collection in the carbohydrate to nitrogen ratio in the bases of the cuttings of Tanche and Gordal Sevillano olive varieties.

\begin{tabular}{cccc}
\hline \multirow{2}{*}{ Cuttings collection dates } & \multicolumn{2}{c}{ Variety } & Dates effect \\
\cline { 2 - 3 } & Tanche & Gordal sevillano & \\
\hline 1 February & 0.570 & 0.111 & 0.341 \\
& $\mathrm{~b}$ & $\mathrm{c}$ & $\mathrm{b}$ \\
\hline 1 March & 0.473 & 1.091 & 0.782 \\
& $\mathrm{~b}$ & $\mathrm{a}$ & $\mathrm{a}$ \\
\hline 1 April & 0.108 & 0.521 & 0.314 \\
& $\mathrm{c}$ & $\mathrm{b}$ & $\mathrm{b}$ \\
\hline Variety effect & 0.384 & 0.574 &
\end{tabular}

increase in the proportion of carbohydrates to nitrogen ( $\mathrm{C} / \mathrm{N}$ ratio), which is reflected positively on the increase in the proportion of rooting and some characteristics of the root total studied. It is clear from the table data that the variety has a significant effect on the increase in the ratio of carbohydrates to nitrogen ( $\mathrm{C} / \mathrm{N}$ ratio), where the superiority of the olive cuttings of Gordal Sevillano variety in the increase of this percentage was $(0,574 \%)$ significantly on the cuttings of the olive Tanche which amounted $(0.384 \%)$ increasing the ratio of carbohydrates to nitrogen ( $\mathrm{C} / \mathrm{N}$ ratio),

The result is attributed to an increase in the proportion of carbohydrates in the cuttings of the olive variety Gordal Sevillano compared to the Tanche species and the difference in nitrogen ratio in both varieties. Table (5) revealed that the interaction of the dates of taking the cuttings with the variety has a clear effect on the increase in the ratio of carbohydrates to nitrogen ( $\mathrm{C} / \mathrm{N}$ ratio). The olive cuttings of the variety Gordal Sevillano, which was obtained on 1 March, was
(190.1\%) significantly higher than that of other factors in increasing the ratio of carbohydrates to nitrogen ( $\mathrm{C} / \mathrm{N}$ ratio).

These data indicate that the orchard is subject to horticultural services of good fertilization, pruning and pest control, which has a positive effect on rooting rate and a number of root and vegetable root of cuttings. This may be due to the combined effect of the three factors under study and the reasons cited for each individual explanation.

\section{Conclusions}

The present work suggests that rooting percentage were get from the treatment of Gordal Sevillano variety which collected on the $1^{\text {st }}$ March treated with $4000 \mathrm{mg} . \mathrm{l}^{-1}$ were gave $66.67 \%$. Highest rate of survival $(80.0 \%)$ of control treatment of Tanche olive variety were taken on $1^{\text {st }}$ of February. The highest content of carbohydrate were obtained in Gordal Sevillano basal cuttings were taken on $1^{\text {st }}$ of March. The highest percentage of $\mathrm{C} / \mathrm{N}$ ration were got by 
interaction of Gordal Sevillano which collected on $1^{\text {st }}$ of March.

\section{Acknowledgements}

Thanks to staff of Department of Horticulture and Landscape Design and its Laborites, for their helps to determination and analysis, and College of Agriculture and Forestry, University of Mosul.

Conflict of interest: The authors declare that they have no conflict of interest.

\section{References}

Al-Dolaemi, Sh.Y.A. (2012). Effect of cuttings collection dates, indol-butyric acid (IBA) and Hydrogen peroxide $\left(\mathrm{H}_{2} \mathrm{O}_{2}\right)$ in olive cuttings rooting. M.Sc. Thesis. Coll. Agric. Univ. Al-Anbar: 96pp.

Al-Imam, N.M.A (2011). Effect of some factors on rooting percentage and subsequent growth of "manzanillo" olive cuttings. Mesopotamia J. of Agric., 39(2): 9-19.

Alsahaf, F.H. (1989). Applied Plant Nutrition. Bait Alhikma, Univ. Baghdad, Min. High. Educ. Sci. Res.: 259pp.

Barcelo, A.M.; Encina, C.L. \& Perez, E.S. (1999). Micropropagation of adult olive. PI. Cell Tissue Organ, Cult., 36(3): 321326.

Dubois, M.; Gills, K.A.; Hamilton, J.K..; Robers, P.A. \& Smith, F. (1956). Colorimetric method for determination of sugars and related substance. Anal. Chem., 28(3): 350-356.

Garcia, M.L.G.; Romero, C.S.; Munoz, A.B.; Heredia, A. \& Pliego-Al Faro, F. (1994). Levels of endogenous indole-3-acetic acid and indole-3-butyric acid during adventitious rooting in avocado micro cuttings. J. Exp. Bot., 45(6): 865-870.

Hartmann, H.T.; Kester, D.E.; Davis, F.T. \& Geneve, R.L. (2014). Plant propagation, principles and practices, $8^{\text {th }}$ ed. Prentice upper saddle river -Hall, lac,. New Jersey: 927pp.

Hechmi, M.; Khaled, M.; Abed, S.; ElHassen, A.; Faiez, R. \& Mhamed, A. (2013). Performance of olive cuttings (Olea europaea L.) of different cultivars growing in the agro-climatic conditions of Al-Jouf (Saudia Arabia). Am. J. Plant Physiol., 8(1): 41-49.

Hopkins, W.G. \& Hüner, N.P.A. (2004). Introduction of plant physiology. $3^{\text {rd }}$ ed. John Wiley and sons, Inc.: 523pp.

Jindia, H. (2003). Fruit Trees Physiology. Arabic Pub. House. Egypt: 471pp.

Ling, W.X. \& Zhong, Z. (2012). Seasonal variation in rooting of the cuttings from tetraploid Locust in relation to nutrients and endogenous plant hormones of the shoot. Turk. J. Agric., 36: 257-266.

Maghsudlu. M.; Afshari, H. \& Faraji, A. (2013) The evaluation of the effect of different IBA (indole-3 butyric acid) hormone concentrations and different kinds of cutting on rooting of two compatible olive cultivars cuttings in Golestan Province. Bull. Env. Pharmacol. Life Sci., 2(6): 82- 88.

Roger M. R.N.C. \& Hasted, A.M. (2003). Statistical Methods in Agriculture and Experimental Biology. Chapman. $3^{\text {rd }}$ ed. Hall, A CRC Press Co., Washington, D. C. 488pp.

Ruiz, G. \& Loreto, A. (1998). Effect of the application of IBA and date of collection 
on the rooting of semi-hardwood cutting of olive (Olea europaea L.) cultivar “Sevillano". Olivae.,74: 58-61.

Souidan, A.A.; Zaued, M.M \& Dessouky, M.T.A. (1995). A study on improving the rooting of Ficus elastica L. var. decora stem cuttings .I .The effect of some auxin treatments .Ann. Agric. Sci. Ain-Shams Univ., Cairo, 40(2): 821-829.

Ullah, E.; Awan, A.A.; Abbas, S.J.; Masroor, F.S. \& Khan, O. (2012). Growth response of various Olive cultivars to different cutting lenghs. Pak. J. Bot., 44(2): 683686.

Wiesman, Z. \& Lavee, S. (1995). Enhancement of IBA stimulatory effect on rooting of olive cultivar stem cuttings. Sci. Hortic., 62: 189-198.

Wynne, J. \& Mcdonald, M.S. (2002). Adventitious root formation in woody plant tissue: The influence of light and indole-3-butyric acid. In Vitro Cell Dev. Biol. Plant., 38(2): 210-212. 